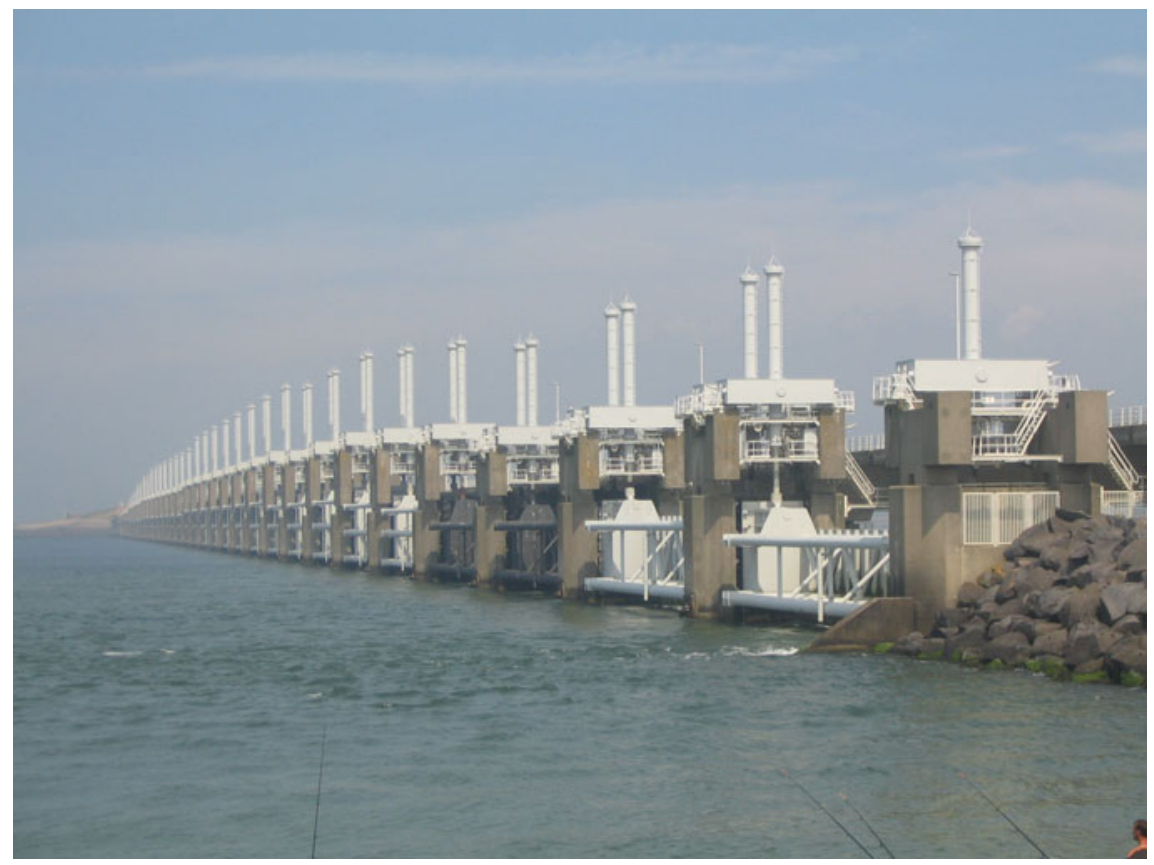

The flood gate Oostertscheldekering, a Dutch Delta work, Wikimedia, released under a creative commons attribution 3.0 Unported license 


\title{
Chapter 1 \\ Introduction: Connecting Water and Heritage for the Future
}

\author{
Carola Hein, Henk van Schaik, Diederik Six, Tino Mager, \\ Jan (J. C. A.) Kolen, Maurits Ertsen, Steffen Nijhuis \\ and Gerdy Verschuure-Stuip
}

\begin{abstract}
Water has served and sustained societies throughout the history of humankind. People have actively shaped its course, form, and function for human settlement and the development of civilizations. Around water, they have created socioeconomic structures, policies, and cultures; a rich world of narratives, laws, and practices; and an extensive tangible network of infrastructure, buildings, and urban form. Today, the complex and diverse systems of the past are necessarily the framework for preservation and reuse as well as for new systems. Through twentyone chapters in five thematic sections, this book links the practices of the past to a present in which heritage and water are largely two separate disciplinary and professional fields. It describes an alternative emerging present in which policymaking and design work together to recognize and build on traditional knowledge and skills while imagining how such efforts will help us develop sustainable futures for cities, landscapes, and bodies of water.
\end{abstract}

Keywords Water heritage $\cdot$ Adaptive reuse $\cdot$ Policymaking $\cdot$ ICOMOS $\cdot$ Center for Global Heritage and Development $\cdot$ Dutch water and heritage practice $\cdot$ Water and heritage agenda

C. Hein $(\varangle) \cdot$ T. Mager $\cdot$ M. Ertsen · S. Nijhuis $\cdot$ G. Verschuure-Stuip Delft University of Technology, Delft, The Netherlands

e-mail: C.M.Hein@tudelft.nl

H. van Schaik · D. Six

ICOMOS, Amsterdam, The Netherlands

J. (J. C. A.) Kolen

Leiden University, Leiden, The Netherlands

(C) The Author(s) 2020

C. Hein (ed.), Adaptive Strategies for Water Heritage,

https://doi.org/10.1007/978-3-030-00268-8_1 


\section{Introduction}

Water has always been a central human concern. The earliest prehistoric hunters and gatherers, although nomadic, also settled down along rivers, lakes, and coastlines to ensure access to crucial resources-including water. Later, prehistoric farming societies manipulated water systems and redirected water to meet their essential needs. Early states managed water resources with large-scale facilities like aqueducts, irrigation systems, and polders. They used water to cultivate the earth for drinking, food, and agriculture. No less importantly, water became a key element in their complex social organizations and political ideologies. People around the world have both used water as a means of defense and have learned to defend themselves against water, in the form of floods from river and sea. At the same time, the water in rivers, lakes, and oceans facilitated trade networks and the exchange of goods, people, and ideas. This led, among others, to the development of extensive port cities that connected local communities with the rest of the world.

Over millennia, people have created immensely rich and varied, often interconnected, systems to manage water: in lowlands and mountains, wetlands and deserts, agricultural landscapes, urban networks, and on urban waterfronts. Today, those systems are heritage - a term used here broadly to encompass both recognized World Heritage Sites as well as the historic built environment that people have chosen to preserve. This heritage is often also still vital and functional. It can range in size from ingenious small-scale water harvesting systems and aqueducts to larger water pumping facilities and irrigation and drainage networks, dike systems, and defense systems (Steenhuis 2015; Labanca Correa de Araujo 2015). It includes maritime cultural landscapes, canals, harbors, and waterfronts (Daly 2015; Hein 2011; Meyer 1999) as well as local knowledge and skills and regional traditions in water engineering (Sugiura et al. 2015; Scarborough 2003).

Water heritage is found in spaces that are closely linked to traditions, rituals, and narratives. The hydraulic network at Angkor served both the physical infrastructure and the ritual network of sacred places and temples (Hang 2015). In the Dutch delta, the elements of the infrastructure for water management-dikes, river forelands, polders, locks, and drawbridges-are icons of Dutch historical identity (Steenhuis 2015). Maritime heritage is spiritually important to local coastal communities in South Africa (Sharfman 2017). Indeed, port cities have a distinctive shared culture (Hein 2016). This heritage is a crucial source of information both for understanding how water systems worked in the past and discerning their impact on the present. It is also a source of knowledge for water managers and environmental engineers; an integral part of architectural and urban design; as well as a site of cultural identification, historical experience, public engagement, leisure, and tourism.

A few scholars have examined select aspects of the management of water and heritage. Maritime archeologist Christer Westerdahl introduced the notion of maritime cultural landscape to name and better explore, study, and preserve the networks present between communities based on travel and trade over water, be they oceans, seas, inland lakes, rivers, or artificial waterways. These networks included social 
and political relationships as well as their associated ancient routes, harbors, shipyards, settlements, and other physical structures (Westerdahl 1992). The historians Jerry Bentley, Renate Bridenthal, and Kären Wigen have coined the term seascape to capture the history of maritime regions around the world (2007). The journal Water History explores the historical relationship between people and water resource use, but does not specifically engage heritage or the seas and oceans. Planning historians have published extensively on waterfront redevelopment and the role of port-related heritage structures. Architectural and planning historian Carola Hein has proposed the concept of port cityscapes, arguing that the reach of the port into its neighboring city and region merits comprehensive investigation (2011, 2016). Planner Han Meyer and landscape architect Steffen Nijhuis have pointed to the need to study urbanized deltas and the dual challenges of river and sea water (2014). Other planners and landscape architects have explored issues of design, water, and heritage. The work on hydro-biographies stands as an example (Land-id, Beek and Kooiman 2014; Bosch and Soree 2016). At the institutional level, the Ramsar Convention is an intergovernmental treaty for the preservation and wise use of wetlands; its work encompasses their natural and cultural heritage (Ramsar 1994). In addition, UNESCO's World Heritage Center has published a special issue, Living with Water (2011). And the International World Water System Heritage Program, launched in 2016 by the World Water Council in collaboration with the International Commission on Irrigation and Drainage, has initiated a registrar for the intangible values of water-related heritage.

But these initiatives and studies in historical, urban, and geographical research have had only tangential influence, if any, on the practice and policy of water heritage management of diverse typologies - from buildings to landscapes, from engineered structures to nature conservation. Overall, academics, policymakers, designers, and the public alike largely perceive heritage and water as separate worlds, represented by different sectors and organizations; informed by different philosophies, scientific disciplines, policy frameworks, and design concepts.

Although water and cultural heritage are linked through complex interrelationships, each is approached from siloed perspectives. Water is examined along the disciplinary lines of science, engineering, governance, and management, whereas cultural heritage is often looked at as comprising isolated structures rather than as consisting of elements of a larger system. And researchers often miss water itself altogether. Overall, water's potential to connect sites of living heritage with each other; water-related heritage's capacity to connect past, present, and future; and water's role as heritage in spatial developments, landscape design, and urban planning remain underestimated and underexplored. Moreover, water-related policymaking is highly segregated within itself, with different specialists dedicated to investigating drinking water, tourism and recreation, nature and biodiversity, transport and mobility, safety and security, and so on. Top-down approaches dominate all of these fields. Moreover, many are primarily land-based, that is, connected to national agendas and focused upon water that is on or related to land.

Today, global climate change, pollution, and changing political and societal patterns affect both water and heritage on multiple scales; these include systems for drinking water, irrigation, and drainage as well as the heritage of coastal areas, deltas, 
and port cities (Lieske et al. 2015; Okamura 2015; Comer 2015; also see Statement of Amsterdam (1999; Willems and Van Schaik 2015). Rising seas challenge Pacific archipelagos (Peterson 2015) and the coastal plains and major port cities of the southern and eastern parts of the USA, while flooding rivers threaten cities and towns in the Low Countries, Cambodia, and Bangladesh. Conversely, severe droughts and desertification, resulting in land degradation in other parts of the world, challenge the livelihood of millions of people. Other climate-change-driven challenges, including expected food shortages and mass migration, underscore the need to rethink our longstanding relationship with water, culture, and our built heritage. The future of water and heritage structures also depends on political, economic, environmental, cultural, and spatial frameworks, including globalization and the privatization of water and heritage structures. The growing and changing pollution of canals, rivers, and seas - notably, the threat of plastic waste to nature, people, and structures - also warrants new forms of inquiry and design. The energy transition, and the design steps needed to achieve it, will also create new kinds of heritage in the future. Vast areas of ports and petroleum installations are just one example of potential future water-related heritage sites.

History and heritage matter when we design new relationships with water. Waterrelated heritage preserves and transmits forgotten best practices and catastrophic events. It harbors the long histories of water systems and safeguards our cultural memory for generations to come. New investigations of water history and heritage can serve as a source of information, inspiration, and identity-building in water management, wetland recreation, and marine engineering; they are relevant to the redevelopment, redesign, and reuse of existing and ancient water systems as well as to the design of new systems. The reuse, adaptation, or redesign of old systems can contribute to the quality of life of communities and other groups, and to their sense of place and self-identification. Finally, understanding and analyzing the relationship between water and heritage can also help us refine our understanding of tangible and intangible heritage more broadly.

This volume brings new voices to this important and urgent multilateral project at the interface of water and cultural heritage and shows how we might address its concerns in both scientific research and research-based policymaking. It is one of many undertakings carried out by ICOMOS Netherlands, the Dutch branch of the International Council of Monuments and Sites, which has sponsored a range of initiatives: conferences, events, books, and even this volume at all geographical and governmental scales, from the local and regional to the international and global, in order to stimulate thinking about the interrelationships between cultural heritage and water management. The rich and agenda-setting contributions of ICOMOS Netherlands to this challenge are discussed more extensively below. It is, nevertheless, worth noting that its work, along with that of the Centre for Global Heritage and Development (CGHD) of Leiden University, Erasmus University Rotterdam, and Delft University of Technology, is rooted in the long Dutch history of water-related heritage. 


\section{The Dutch Connection: Water and Heritage in the Netherlands}

The Netherlands is an exemplary delta region in which a dynamic society with a growing population and an increasingly urbanized landscape-rich in heritagehas long faced the challenges of large-scale water management. The country has a centuries-long history of water management which encompasses drinking water supply systems, irrigation and drainage for agriculture, coastal protection, river management, canals, ports, and the use of water as a means of military defense. What was once pioneering infrastructure is now cultural heritage: The Dutch delta illustrates the peculiar position water and heritage occupy well. On the one hand, water management heritage in the Netherlands is extremely rich, historically layered, large-scale, omnipresent, and strongly tied to national and regional issues of cultural identification (Van Gorp and Renes 2003). Dutch contributions to UNESCO's World Heritage List primarily consist of monuments and structures from the country's longstanding engagement with water and the sea. Amsterdam's seventeenth-century canal ring, the Beemster Polder, reclaimed from a lake with the help of windmills by 1612; Kinderdijk, a concentration of windmills for draining polderland from around 1740; the Defense Line of Amsterdam, a military defense line built from 1883 to 1920; the Ir. D. F. Woudagemaal, a steam-driven water pumping station from 1920; and the former island of Schokland, a strip of peatland that lost its island character with the construction of the Noordoostpolder in the 1940s animate the list. On the other hand, this water-related heritage is, at best, only introduced into discussions about the delta's future and the quality of life of its inhabitants and visitors in a meager way. Few consider the area's water-related cultural heritage as a source of information or inspiration for the necessary development and innovation of water governance, engineering, or design - a topic which is also explored by the Organization for Economic Co-operation and Development (OECD 2014).

The Dutch have long debated the very definition of water management heritage. Since the early 1990s, when the Dutch delta was threatened by floods, two different perspectives have developed on the history and heritage of water management, as well as on how to deal with the rapidly changing hydrological situation (Landschap als Geheugen 1993; Van de Cammen and De Klerk 2003; Ruimte voor de Rivier 2007; Van Toorn 2011). One group sees heritage within the continuity of cutting-edge engineering and strategies of water management, while the other aims to preserve the heritage of the physical water structures of the past. Engineers, planners, and nature conservationists propose that the water-related heritage of the Dutch delta is, in fact, largely, an intangible tradition of innovative engineering and skillful water management, that is, of finding new solutions for changing environmental and hydrological conditions. From this perspective, it is necessary to reshape the river landscape and its heritage at a profound level. It is also essential to fundamentally make the delta “climate-change proof" for the future (Kolen et al. 2014, 178). The typical Dutch river landscape and management system with its closed dikes, artificial river forelands (the uiterwaarden), and sunken polders, now the pride of Dutch identity and 
water management, is outdated and could even have catastrophic effects. In keeping with the emphasis on innovation as against the physicality of water structures, the Rijkswaterstaat-literally, the agency in charge of the national water level and effectively in charge of water management and infrastructure-set up a program called Room for the River to provide rivers experiencing high water levels more space free from development. The IJssel River, for example, is being deepened for navigation, and a high water channel between two dikes has been constructed to run parallel to it. Space is created to enable the river to move more freely through the landscape and to facilitate nature's own restoration of biodiversity within newly created wetlands. What continues and what counts as water management heritage to these actors is the successful tradition of innovation: of finding smart technical solutions for complex water issues (Nienhuis 2008; Hoeksema 2006; Huisman 2004). In contrast, some heritage managers have adopted a somewhat different perspective on water-related heritage. They stress the importance of existing water management structures as valuable cultural heritage and icons of Dutch national identity. For them, it is the physical structures of water management, such as the closed dike systems which Dutch engineers and planners started in the Middle Ages and which gained their current form in the second half of the nineteenth century, that have to be preserved. Occasional floods are considered to be part of a system which has never been and will never be perfectly safe (Kolen et al. 2014, p. 179).

This binary dialogue between water and heritage sectarians is unproductive. In recent years, a new approach has emerged in the Netherlands that combines both kinds of heritage work: technological creativity and historic preservation. The Belvedere Memorandum in heritage management and its incentive program (1999-2009) laid out a decade of national policy to integrate heritage management with new spatial developments through historically informed design. It has produced promising experiments in connecting heritage and water issues on a local scale (Belvedere Memorandum 1999; Janssen et al. 2014). With this dynamic approach, new solutions can be found through reusing old hydraulic systems or creating new ones by applying historic approaches. The approach even facilitates interventions in line with sustainable practices, as can be seen in recent research on large-scale water systemssome of which has been published in the Polder Atlas (Steenbergen, et al. 2009). The Dutch Heritage Department pursues a similar strategy, exploring sustainable practices for classified heritage structures (Rijksdienst 2018). Heritage groups and planners around the world can benefit from these experiments and insights.

\section{The Water and Heritage Agenda at ICOMOS}

Given the obvious ties between the Netherlands and water-related heritage, ICOMOS Netherlands first sought to solidify the few existing relationships between the worlds of water and heritage management. Between 2013 and 2018, it convened a number of expert meetings and workshops to develop its water and heritage agenda. The group presented many lectures on the topic at international confer- 
ences outside the Netherlands. Its goals aligned with the UN agenda, as identified in the Sustainable Development Goals (SDG) (UN 2015). In September 2013, ICOMOS Netherlands organized a five-day international conference entitled "Protecting Deltas, Heritage Helps!" which brought together many experts and representatives of governmental, nongovernmental, and intergovernmental organizations from all over the world to share experiences. All invited representatives, partners, and experts expressed urgency regarding the integration of heritage and water management at local, regional, and international scales, while recognizing the equally urgent need for a global exchange of experiences and best practices. To celebrate efforts and achievements in connecting water and heritage for the future, ICOMOS Netherlands also developed the "water and heritage monument shield", an award it first presented in 2013 to the city of Amsterdam (Six and Luijendijk 2015, p. 12). The conference resulted in the Statement of Amsterdam, which called on water and heritage stakeholders, institutions, and specialists to collaborate on active research, education, and communication in order to advocate for the recognition of water and heritage as one connected theme rather than as two independent fields (Willems and Van Schaik 2015).

In 2015, ICOMOS Netherlands published an edited and peer-reviewed volume, Water \& Heritage: Material, Conceptual, and Spiritual connections (Willems and Van Schaik 2015), based partly on papers presented at the 2013 conference. It opens with this statement by Mrs. Irina Bokova, then, the Director-General of UNESCO:

From the beginning of time, humanity has sought out sources of water to sustain life, health and the ecosystems on which they depend. This is especially true today, in this turning point year for the international community, as States shape a new global sustainability agenda. Limiting the impacts of floods, landslides, and droughts, water security and cooperation are basic requirements to improving lives and to empowering people to overcome hunger and disease. The stakes are high. Peace and democracy thrive when people and cultures cooperate for water. Literacy, gender equality, economic development, respect for human rights, freedoms, and diversity-all of these depend on water security (Bokova 2015, p. 9).

Following from this theme of crisis, the authors argued that:

Saving the deltas of the world will be one of the most critical challenges for a sustainable future of humankind. Exposure to water-related hazards, especially due to climate change resulting in higher frequency and intensity of disasters, together with an increasing population density and richness in cultural and natural heritage puts communities, particularly in the world's deltas, at high risk. Rapid urbanization of delta areas without respecting the historic water structures accumulated over the centuries make these areas, in which economic, social, and cultural values are concentrated, even more vulnerable (Six and Luijendijk 2015, 11).

The current volume heeds this call and builds upon these events and publications to investigate deeply a range of heritage sites and to explore the implications and opportunities they offer to future design. It is also partly based on a two-day conference entitled, "Water and Heritage for the Future," held in November, 2016. The conference was organized through close collaboration by ICOMOS Netherlands and the Center for Global Heritage and Development.

The first day of the conference, held at Delft University of Technology's Faculty of Architecture and the Built Environment, brought together a large and varied group 
of scientific researchers in spatial planning, urban design, landscape architecture, civil engineering, water management, history, anthropology, and archeology. The second day was held at Fort Vechten, located where the New Dutch Waterline-a water-based defense line-intersects with the Limes, the former Roman frontier near the city of Utrecht. The conference gathered experts in policymaking, legislation, and applied research. Following these events, a team of Dutch researchers collaborated to develop a research agenda; a foundation for collaboration and dialogue with researchers from other disciplines, areas of work, and nationalities; a charter for an international scientific group; and the initiation of an international scientific board. Along with our current book, the draft agenda identifies a number of research topics on water heritage that partly coincide with those identified here and go beyond them. They include: water for services, that is, for systems of drinking water provision and sewage; irrigation and drainage infrastructure; and natural and man-made waterscapes, including reclaimed land areas, defense structures, and the larger matter of water-related transport systems-concerns which this book addresses. The agenda adds water power, that is, water as a means of energy generation and as a destructive force, along with worldviews: encompassing the role of water in the philosophy of life or conception of the world and its built spaces. The draft agenda is designed so that future issues may be added including, for example, environmental pollution and climate change.

In December 2017, at the nineteenth ICOMOS General Assembly in Delhi, ICOMOS Netherlands presented an informal proposal to a meeting of the larger body's scientific board meeting to initiate the International Scientific Group on Water and Heritage. The scientific board expressed appreciation for the initiative and encouraged ICOMOS Netherlands to prepare a formal proposal. During the General Assembly in Delhi, the Taiwan International Institute for Water Education (TIIWE) offered to host an international conference on water and heritage as part of the preparatory process for the International Scientific Group.

\section{This Book and Its Structure}

This book is a stepping stone in the process of developing international scientific interest and an international scientific agenda on water and heritage. It brings into discussion water and heritage issues through the lens of international cases, while providing deeper insight into the Dutch case. It explores five thematic areas related to water heritage: infrastructure designed for drinking water; agricultural sites engineered for irrigation and drainage; areas gained by poldering and other land reclamation in agriculture, settlement, and defense systems; river and coastline planning; and urban and engineered structures in ports and on waterfronts. Each chapter first addresses larger themes of water heritage, ranging from policymaking to narratives and from sociocultural meaning to subjectivity, before exploring case studies and concluding with future-oriented solutions for heritage practice. 
The book opens with an exploration of freshwater services through time and space, the preservation of infrastructure, its redesign, and potential for inspiring future design. As Meisha Hunter's examination shows, intricately engineered systems have served large populations. Partly due to their service role in traditional water systems, these systems, distinguished for their utility, have received less attention than World Heritage Sites listed for their aesthetics, although infrastructural sites can teach us much that will help us respond to future crises. Areas in which the provisioning of water suffers from ongoing or accelerated desertification are equally threatened. Systems such as the qanat of the Middle East and northern Africa are often extremely vulnerable to relatively small changes in climate, precipitation, political and social organization, and the exchange and transmission of local specialized knowledge (as noted in Pangare and Pangare 2015). Negar Sanaan Bensi explains that the qanat system is not just heritage to be preserved as reminder of a past, but an ongoing element of the culture and civilization on the Iranian Plateau. Relatedly, what seem essentially to be water management interventions, such as the drilling of deep wells after World War II, have larger governmental and cultural implications, which must be acknowledged so as to benefit future interventions.

Araceli Rojas and Nahuel Beccan Dávila demonstrate the relevance for the future of design proposals that build on and derive from historic water systems. In Monte Albán, a site which originates in ancient Oaxaca and has been a UNESCO World Heritage Site since 1993, the supply system of water-mainly consisting of natural rivers and tributaries-has defined the infrastructure of settlements while serving as vessels of ritual meaning. Looking ahead, they suggest that design solutions based on the historic water system can inspire designers to formulate new strategies for preserving the natural environment and archeological heritage, while improving living conditions for local people. Suzanne Loen deepens understanding of the Dutch heritage in freshwater management, a field whose traditional decentralized practices of public and private rainwater harvesting largely disappeared at the advent of centralized water supply systems. Her goal is to show the potential this heritage contains for creating an integrated approach to water supply, landscape conservation, and water-secure livable cities.

Other historic engineered water infrastructure systems include those that improved agricultural land like meadows and rice paddies, structures that are intimately related to modes of societal organization and narrative construction. Hans Renes, Csaba Centeri, Sebastian Eiter, Bénédicte Gaillard, Alexandra Kruse, Zdeněk Kučera, Oskar Puschmann, Michael Roth, and Martina Slamova explore the ways in which the restoration of derelict water meadows in northwestern and central Europe, Slovakia, and Norway can help create and advance regional identity on a European scale and, at the same time, restore biodiversity, improve water retention capacity, and promote tourism and local understanding of historical cultural values. Alexandra Kruse and Bernd Paulowitz complement this investigation with insight into the ways in which Dutch land reclamation technology expanded throughout Europe in the form of the Holler colonies, tangible evidence of a common European economic and social history. Izumi Kuroishi rounds out this investigation into agricultural irrigation by exploring the history of irrigation in Japan's Sanbonkihara rice paddy region in rela- 
tion to cultural practices, narratives, and festivals that have shaped the community around agricultural heritage. Many historical water structures both addressed the water-related needs of a location and created social communities. Modern technological interventions often ignored this intricate balance. Recent climate shifts have emphasized the shortcomings of these systems, as the case of the Taiyuan Tableland illustrates-where a pond and canal system originally built under the influence of generations of foreign colonists, immigrants, and experts has deteriorated. Locals, using what authors Sinite Yu, Chung-His Lin, Hsiaoen Wu, Wenyao Hsu, and YuChuan Chang call participatory narrative weaving, have successfully challenged further development plans for the area.

Water management on land can take on various forms: creating land for agriculture or urbanization and defending that land against attacks. In coastal and alluvial lowlands all over the world (Nijhuis et al. 2019), historic water management projects blocked water from some areas of land and controlled water levels artificially so people could live and work on the reclaimed land. This often centuries-old interaction between human beings and water has produced a rich variety of polder landscapes. Increasing flood risk due to sea level rise and increased climate turbulence, ongoing subsidence due to intense drainage, and rapid urbanization all call for protective action. Three chapters explore the spatial and social construction and meaning of polder landscapes. Yasunori Kitao sets the stage with a careful analysis of the sociocultural aspects of the construction of the Hachirogata polder in Northern Honshu, the largest and most highly populated island of Japan. The polder is celebrated as an important industrial heritage; however, its narrative rarely acknowledges the traditional fishing practices destroyed by its very construction. Steffen Nijhuis complements the Japanese polder heritage exploration, focusing on the preservation and development of the Dutch Noordoostpolder-built in the twentieth centuryand its consequent development as a cultural heritage landscape. The construction of polders, which notably involved Dutch expertise, is a Europe-wide phenomenon and one that may support the creation of a common identity. The Europolder program discussed by Hildebrand de Boer showcases the contemporary benefits of these heritage sites for tourism and regional identity. Other human interventions in water management were designed to protect land against invasion. A unique example of such a large-scale historical water-related site that has been preserved and redesigned is the New Dutch Waterline, an historic defense line. This intervention is examined by Gerdy Verschuure-Stuip. The preservation of this large monument has provided an innovative design connection between water, heritage, and tourism at entirely new scales of intervention.

People around the world have created a broad range of heritage practices along riverbanks and on river waterfronts. Andrew Law examines the Yangtze River as an evolving landscape, what he calls a heritage of becoming. His contribution raises the matter of new digital technologies, including augmented reality tools and their potential to shape heritage debates. The necessity of conceiving of heritage as part of a long-lasting creative process in spatial transformation and public and private participation is also at the heart of Arie den Boer's contribution, which argues that cultural heritage in the Netherlands and elsewhere involves construction and reconstruction, 
use and reuse, public and private stakeholders and civil society over time. A detailed analysis of industry closures, undervalued heritage, along with recent attempts at revitalization shows both the power and opportunities of artistic and cultural projects and of participatory approaches. Sander van Alphen explores how Dutch engineers have responded to the results of centuries of water management by providing new spaces for rivers in the Netherlands, thus addressing questions of both safety and spatial quality. These include the genesis of an attractive living environment and a valuing of the presence of cultural history. Coastal heritage, its natural sources, towns, and buildings are also at the core of Linde Egberts' contribution. She explores the need for coastal regions in Europe to work together to address the common challenges and shared opportunities of coastal tourism. As she appropriately reminds us, old coastal towns were better connected to other port cities over the sea than some of their neighbors on land.

The last group of chapters considers ports and waterfronts. Azadeh Arjomand Kermani, Wout van der Toorn Vrijthoff, and Arash Salek add insights on interactions between ports and their cities, showing how Rotterdam has redeveloped its old harbor heritage. It explores both the history of the former shipbuilding company RDM (Rotterdamsche Droogdok Maatschappij) and the city's renewal of the waterfront to attract cruise ship tourists. The opportunities and challenges posed by cruise ships and their impact on port cities and waterfront heritage become evident in the work of Sofia Saavedra Bruno, Martin Delgado, and Felix Madrazo. Collaborating under the name of Supersudaca, they examine the historical and contemporary logics of the emergence of Caribbean heritage and recent fake heritage buildings in Caribbean cruise destinations. José Manuel Pagés Sánchez and Tom Daamen link waterfront redevelopment to the role of heritage in the sustainable development of the Lisbon historical maritime waterfront, emphasizing the switch from an object-based to a landscape-based approach to heritage. This strategy is based on a governance process that facilities collaboration between port and city authorities. Han Meyer concludes this series of inquiries into port, city, and waterfront relationships by emphasizing that cultural heritage is constructed on our selective understanding of the past. He asserts the need to recognize that buildings, deltas, and nature itself are adaptive and evolutionary, such that we can move from a narrative of human engineering resisting nature, as it has emerged in the twentieth century, to one of dynamic adaptation. Such a reconsideration of cultural heritage is particularly necessary at this time of climate change and the many attendant challenges it holds for urbanized delta regions. Extensive heritage sites on urban waterfronts and working ports and cities are of particular concern. He contends that the cultural and natural heritage of urbanizing deltas itself will help us develop an adaptive approach, not as a complete departure from present ways of doing things, but as a new stage in a centuries-long tradition.

Water heritage systems throughout the world are comprised of physical and functional structures, conceptual and organizational principles, and cultural and spiritual values. This stands despite their many differences in geographical location, climate, cultural and political context, economic and social setting, heritage, and future threat. Scholars and policymakers must closely examine these differences to understand and tune research designs and approaches in politics, policy, and management, as well 
as future design opportunities (as noted in Katko et al. 2015). Moreover, historical and archeological studies are often able to clarify when and why systems are more or less efficient and what the conditions of exploitation or overexploitation are in the past, writ large, and in the recent past (as in Comer 2015; de Grenade and Varady 2015). When research into former times is closely linked to forward-looking practices in engineering, architectural design, and planning, we are able to make heritage an integral part of the future as well as a means through which design of future sustainable practices can be achieved. The book's aim is to provide further evidence and opportunity for anchoring this claim and ambition. Rather than an end, our effort seeks to catalyze international interest among policymakers, planners, architects, and heritage specialists to integrate planning with the management of water-related heritage. Because substantiation is only in its beginnings, this book does not contain conclusions but rather ends with a promise that the work will be continued.

The book's five themes examine several of the most important purposes of water management: drinking water supply, agriculture, land reclamation, protection, defense, transport, and trade. Many important subjects have not been touched upon: for example, the role of canals and sewage systems in water heritage, among others, merit further examination. Canals have played a pioneering role in human cultural development. Their planning and implementation requires extensive collective effort as well as good hydraulic and topographical knowledge that specifically includes that of the construction of locks, dikes, bridges, and harbors. Sewage systems have also been of great importance in the development of larger settlements. They have facilitated the hygienic conditions that are a prerequisite for the capacity of larger communities to live together in confined spaces. Today, disposal is a fundamental problem in many overpopulated and fast-growing regions of the world. It is a problem which can be seen in the state of many watercourses, rendered as abused flowing dumps that contribute to marine pollution. This development itself often necessitates restructuring watercourses and constructing reservoirs, which, in turn, entail environmental risks.

Other, larger themes, such as water and energy generation, natural, industrial and urbanized waterscapes, water narratives, legal issues, and education also merit additional attention. For example, water has been used for energy generation for thousands of years. And, today, water power can make a significant contribution as a renewable energy source. Further research into the various ways that using water power can help regions solve local energy problems while safeguarding ecological balance would be of great benefit. To date, the discussion on water and heritage has largely neglected issues of the open sea. New scholarship is emerging on the 'urbanization of the oceans' (their increased use for shipping, raw material extraction, energy production, and the siting of pipelines, cables, and other networks are material concerns). The question of whether and how to preserve drilling rigs and other seabased construction as heritage (Couling 2016; Hein 2018; Couling and Hein 2018) is also now being addressed. These concerns all call for deeper research into historically grounded solutions. The long-term consequences of their consideration can be of help to planners and policymakers in integrating historical knowledge and experience into future-oriented and sustainable solutions that are resilient, balanced, and durable. 
Their investigation and that of other objects of water-related heritage requires a broader approach: Water management systems are components of the water cycle and are thus always integrated into other complex natural and cultural systems. When investigating historical objects, as with other heritage sites, scholars must always consider their economic, ecological, organizational, functional, social, and spiritual aspects. Water management systems play a major role in all world religions and spiritual traditions, whether people use water for baptism, ritual purification, or worship it as the source of life. Overall, past, present, and future water cultures merit further investigation. As Rutgerd Boelens has pointed out, politicians and other institutional leaders - and their institutions-have established water cultures and used engineering to then transform historic water cultures and practices (2015). While his particular exploration notes cases that arise from the Andes, where indigenous control over water rights and territories encounters international policymaking, the practice he posits has precedent elsewhere.

Legal issues related to water also deserve further exploration. Innumerable local conflicts surround water control every day. Further research must address the dynamic mix of local, regional, and global norms and conflicts that emerge with the application of traditional and indigenous water control models. Here, very different concepts of efficiency, participation, and authority meet and require closer investigation as to how pluralism and normative diversity relate to the dominant water governance culture.

A crucial point in successfully applying heritage knowledge to current and future issues of water management is education. Academic and professional programs must combine the many strands of isolated expertise to establish a more comprehensive and holistic understanding of how water-related heritage can help build more inclusive and sustainable futures. Water management, civil engineering, hydrology, and urban and spatial planning must therefore be integrated into heritage management education along with social and legal studies.

Heritage is more than historical objects. First and foremost, it encompasses the richest treasure of experience available to humankind. Learning both from best practices and mistakes in history, from the long-term effects of particular decisions and the complex interrelationships between water and society, we can recognize the full potential of water heritage and apply what is gained. Understanding, using, and sharing heritage calls for knowledge gained through research and is best disseminated through technologies of open access. Little more has greater value in sustainably preparing societies for future climatic and demographic changes.

Ultimately, water-related heritage is not only a product of the past, worthy of protection because it allows future generations to pursue their questions through a consideration of historical objects, it is also a product of research and interpretation in the present. Preserving local structures necessitates addressing contemporary challenges, which, in turn, requires strong local cultures and identities. But these take a long period of time to form. Bottom-up processes and participation must be further researched and supported. Local initiatives and targeted support programs may also be helpful in generating interest and thus facilitating identification, the basis of all commitments. In short, artifacts and practices of the past are important as part of the 
present, to be preserved, to be adapted and reused. They can also become inspirations and foundations for the future; however, we must educate people to see this.

These connections between the material, conceptual, organizational, and cultural-spiritual aspects of water systems, their heritage structures, and future designs form an important point of departure for new initiatives to be executed by ICOMOS, the Centre for Global Heritage and Development of Leiden University, Delft University of Technology, and Erasmus University Rotterdam in the coming years.

\section{References}

Belvedere Memorandum (1999) The Belvedere Memorandum—a policy document examining the relationship between cultural history and spatial planning. Ministerie VROM, Nieuwegein

Bentley JH, Bridenthal R, Wigen K (eds) (2007) Seascapes: maritime histories, littoral cultures, and transoceanic exchanges. University of Hawai'i Press, Honolulu

Boelens R (2015) Water, power and identity: the cultural politics of water in the andes (Earthscan studies in water resource management). Routledge, London

Bokova I (2015) Foreword. In: Willems WJH, van Schaik HPJ (eds) Water \& heritage. Material, conceptual and spiritual connections. Sidestone Press, Leiden, p 9

Bosch JW, Soree C (2016) Hydrobiografie Schelde-estuarium. Bosch en Slabbers Landschapsarchitecten, Den Haag

Comer DC (2015) Water as an agent of creation and destruction at Petra. In: Willems WJH, van Schaik HPJ (eds) Water \& heritage. Material, conceptual and spiritual connections. Sidestone Press, Leiden, pp 231-244

Couling N (2016) Urbanization of the ocean; extractive geometries in the Barents Sea. In: Infrastructure space. LaFargeHolcim forum for sustainable construction. Ruby Press, Berlin

Couling N, Hein C (2018) Blankness: the architectural void of north sea energy logistics. Foot$\operatorname{print}(23)$

Daly K (2015) Preserving New York City's waterfront industrial and maritime heritage through resilient and sustainable development-New York City's coastal development. In: Willems WJH, van Schaik HPJ (eds) Water \& heritage. Material, conceptual and spiritual connections. Sidestone Press, Leiden, pp 155-168

de Grenade R, Varady RG (2015) The Santa Cruz river: four millennia of water heritage and security in the US-Mexico border region. In: Willems WJH, van Schaik HPJ (eds) Water \& heritage. Material, conceptual and spiritual connections. Sidestone Press, Leiden, pp 371-388

Hang P (2015) Water and heritage in Angkor, Cambodia. The monuments, the ancient hydraulic network and their recent rehabilitation. In: Willems WJH, van Schaik HPJ (eds) Water \& heritage. Material, conceptual and spiritual connections. Sidestone Press, Leiden, pp 71-86

Hein C (2011) Port cities: dynamic landscape and global networks. Routledge, New York

Hein C (2016) Port cityscapes: conference and research contributions on port cities. Plann Perspect 31(2):313-326

Hein C (2018) Oil spaces: the global petroleumscape in the Rotterdam/The Hague area. J Urban Hist 44(5):887-929

Hoeksema RJ (2006) Designed for dry feet. Flood protection and land reclamation in the Netherlands. American Society of Civil Engineers, SL

Huisman P (2004) Water in the Netherlands. Managing checks and balances. Netherlands Hydrological Society, Delft

Janssen J, Luiten E, Renes J, Rouwendal J (2014) Heritage planning and spatial development in the Netherlands: changing policies and perspectives. Int J Herit Stud 20(1):1-21 
Katko TS, Juuti PS, Pietila PE, Rjala RP (2015) In: Willems WJH, van Schaik HPJ (eds) Water \& heritage. Material, conceptual and spiritual connections. Sidestone Press, Leiden, pp 297-312

Kolen JCA, van Manen N, de Kleijn M (2014) History matters: the temporal and social dimension of Geodesign. In: Lee DJ, Dias D, Scholten HJ (eds) Geodesign by integrating design and geospatial sciences. Springer, Cham, pp 173-181

Labanca Correa de Araujo E (2015) Heritage values of water and sea defense in Recife. Challenges for a local governmental approach. In: Willems WJH, van Schaik HPJ (eds) Water \& heritage. Material, conceptual and spiritual connections. Sidestone Press, Leiden, pp 169-184

Land-id, Beek and Kooiman (2014) Hydrobiografie van Marken, leven met het water. Arnhem

Landschap als Geheugen (1993) Landschap als geheugen. Opstellen tegen dijkverzwaring. Cadans, Utrecht

Lieske H, Schmidt E, Will T (2015) Flood protection for historic sites. Integrating heritage conservation and flood control concepts. Experiences in Germany. In: Willems WJH, van Schaik HPJ (eds) Water \& heritage. Material, conceptual and spiritual connections. Sidestone Press, Leiden, pp 205-216

Meyer H (1999) City and port: urban planning as a cultural venture in London, Barcelona, New York, and Rotterdam: changing relations between public urban space and large-scale infrastructure. International Books, Utrecht

Meyer H, Nijhuis S (2014) Urbanized deltas in transition. Techne Press, Amsterdam

Nienhuis P (2008) Environmental history of the Rhine-Meuse Delta. Springer, Dordrecht

Nijhuis S, Schultz B, Pouderoijen MT (2019) Polder landscapes of the world. Jap Sam Books, Amsterdam (in press)

OECD (2014) Water governance in the Netherlands: fit for the future? OECD studies on water. OECD Publishing, Berlin

Okamura K (2015) Tsunami and heritage after the 2011 Great East Japan Earthquake. In: Willems WJH, van Schaik HPJ (eds) Water \& heritage. Material, conceptual and spiritual connections. Sidestone Press, Leiden, pp 245-256

Pangare V, Pangare G (2015) Ancient water wisdom. Traditional water systems in India. In: Willems WJH, van Schaik HPJ (eds) Water \& heritage. Material, conceptual and spiritual connections. Sidestone Press, Leiden, pp 57-70

Peterson JA (2015) Pacific islands on the brink of submergence. Rising seas in an age of climate changes. In: Willems WJH, van Schaik HPJ (eds) Water \& heritage. Material, conceptual and spiritual connections. Sidestone Press, Leiden, pp 121-140

Ramsar (1994) Convention on wetlands of international importance especially as waterfowl habitat, with the amendments of 28.5.1987 and certified copy of 13.7.1994 by UNESCO. UNESCO, Paris

Rijksdienst voor het Culturel Erfgoed (2018) Erfgoed telt. https://cultureelerfgoed.nl/dossiers/ erfgoed-telt. Accessed 25 June 2018

Ruimte voor de Rivier (2007) Planologische Kernbeslissing Ruimte voor de Rivier. Ministerie van V\&W, Ministerie van VROM en Ministerie van LNV, The Hague

Scarborough VL (2003) The flow of power. Ancient water systems and landscapes. School of American Research, Santa Fe

Sharfman J (2017) Troubled waters. Developing a new approach to maritime and underwater cultural heritage management in Sub-Saharan Africa, vol 41. Archaeological Studies Leiden University, Leiden

Six DL, Luijendijk E (2015) Preface. In: Willems WJH, van Schaik HPJ (eds) Water \& heritage. Material, conceptual and spiritual connections. Sidestone Press, Leiden, pp 11-13

Steenbergen C, Reh W, Nijhuis S, Pouderoijen MT (2009) The Polder Atlas of the Netherlands. Pantheon of the low lands. Thoth, Bussum

Steenhuis M (2015) The Deltaworks: heritage and new space for a changing world. In: Willems WJH, van Schaik HPJ (eds) Water \& heritage. Material, conceptual and spiritual connections. Sidestone Press, Leiden, pp 331-350

Sugiura M, Sato Y, Ota S (2015) The framework of skills and knowledge shared in long-enduring organizations in the improvement of irrigation efficiency in Japan. In: Willems WJH, van Schaik HPJ (eds) Water \& heritage. Material, conceptual and spiritual connections. Sidestone Press, Leiden, pp 313-330 
UN (2015) Sustainable development goals. 17 goals to transform our world. http://www.un.org/ sustainabledevelopment/sustainable-development-goals

van de Cammen H, De Klerk L (2003) Ruimtelijke ordening. Van Grachtengordel tot Vinex-wijk. Het Spectrum, Houten

van Gorp B, Renes J (2003) The Dutch landscape: W way of seeing. In: van Gorp B, Hoff M, Renes J (eds) Dutch windows. Cultural geographical essays on the Netherlands. FRW, Utrecht, pp 55-75

van Toorn W (2011) Het grote landschapsboek. Querido, Amsterdam

Westerdahl Chr (1992) The maritime cultural landscape. Int J Naut Archaeol 21(1):5-14

Willems WJH, van Schaik HPJ (eds) (2015) Water \& heritage. Material, conceptual and spiritual connections. Sidestone Press, Leiden

World Heritage Center (2011) Living with water. In: World heritage, vol 59, Mar 2011

Carola Hein is Professor and Head of the History of Architecture and Urban Planning at Delft University of Technology. Her books include The Capital of Europe, Rebuilding Urban Japan after 1945, Port Cities, and The Routledge Handbook of Planning History. She currently works on the transmission of planning ideas among port cities and within landscapes of oil.

Henk van Schaik is an Ambassador of Water and Heritage of ICOMOS Netherlands. He was co-editor of the ICOMOS book Water and Heritage: material, conceptual and spiritual connections. He is working on creating an International Scientific group between ICOMOS and its partner organisations to raise awareness of water-related heritage for the future.

Diederik Six is a senior architect who specializes in restoration and reuse as well in new traditional architecture. He is the former president of the Royal Dutch Antiquity Society KNOB and president of ICOMOS Netherlands. He seeks to bridge disciplines and build on traditional wisdom for a sustainable future.

Tino Mager studied media technology and art history and the communication sciences. He received his Ph.D. in 2015 from the Berlin Institute of Technology where he was an Elsa Neumann fellow. After research terms and lectureships in multiple locations internationally, he was a research associate at the Chair of History and Theory of Architecture at the Technical University in Dortmund 2015-2017. Currently, he is a postdoctoral researcher at the Chair of History of Architecture and Urban Planning at Delft University of Technology.

Jan (J. C. A.) Kolen is an archeologist and specialist of the history and heritage of cultural landscapes. He is Professor in Landscape Archeology and Cultural Heritage at Leiden University (Faculty of Archeology) and is Director of the Centre for Global Heritage and Development of Leiden University, Delft University of Technology, and Erasmus University Rotterdam.

Maurits Ertsen is Associate Professor in the Water Resources group at Delft University of Technology, The Netherlands. His books include Improvising Planned Development on the Gezira Plain, Sudan, 1900-1980 and Locales of Happiness: Colonial irrigation in the Netherlands East Indies and its remains, 1830-1980. His current work focuses on how short-term actions produce long-term changes in ancient irrigation systems.

Steffen Nijhuis is Head of Landscape Architecture Research, Director European Post-master in Urbanism (EMU), and Associate Professor in the Department of Urbanism, Faculty of Architecture, and the Built Environment, Delft University of Technology. His book publications include The Polder Atlas of the Netherlands, Delta Urbanism, and Polder Landscapes of the World. He currently works on landscape-based strategies for urban development. 
Gerdy Verschuure-Stuip is an architect and assistant professor of landscape architecture at Delft University of Technology. She publishes and teaches on both landscape architecture and heritage issues in the Netherlands. Research topics include country estates and their connection to the landscape, planted avenues, and military heritage.

Open Access This chapter is licensed under the terms of the Creative Commons AttributionNonCommercial-NoDerivatives 4.0 International License (http://creativecommons.org/licenses/bync-nd/4.0/), which permits any noncommercial use, sharing, distribution and reproduction in any medium or format, as long as you give appropriate credit to the original author(s) and the source, provide a link to the Creative Commons license and indicate if you modified the licensed material. You do not have permission under this license to share adapted material derived from this chapter or parts of it.

The images or other third party material in this chapter are included in the chapter's Creative Commons license, unless indicated otherwise in a credit line to the material. If material is not included in the chapter's Creative Commons license and your intended use is not permitted by statutory regulation or exceeds the permitted use, you will need to obtain permission directly from the copyright holder.

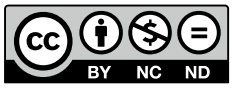

